\title{
Paracrine Activation of the Wnt/ $\beta$-Catenin Pathway by Bone Marrow Stem Cell Attenuates Cisplatin-Induced Kidney Injury
}

\author{
Xiaoyan Jiao ${ }^{a, b, c} \quad$ Jieru Cai ${ }^{a, b, c} \quad$ Xiaofang Yu ${ }^{a, b, c, d} \quad$ Xiaoqiang Ding ${ }^{a, b, c, c, d}$ \\ aDepartment of Nephrology, Zhongshan Hospital, Fudan University, 'bShanghai Medical Center for \\ Kidney, 'Shanghai Key Laboratory of Kidney and Blood Purification, 'Shanghai Institute of Kidney and \\ Dialysis, Shanghai, China
}

\section{Key Words}

Acute kidney injury • Cisplatin-induced kidney injury • Bone marrow mesenchymal stem cell • Wnt/ $\beta$-catenin pathway $\cdot$ Paracrine effect

\begin{abstract}
Background/Aims: Cisplatin-induced acute kidney injury (AKI) involves damage to tubular cells via excess reactive oxygen species (ROS) generation. Stem cell-based therapies have shown great promise in AKI treatment. In this study, we aimed to assess the protective effect and mechanism of bone marrow mesenchymal stem cell (BMSC)-derived conditioned medium (CM) against cisplatin-induced AKI. Methods: In vitro, NRK-52E cells were incubated with cisplatin in the presence or absence of $C M$, followed by the assessment of cell viability, apoptosis and cell cycle distribution. Then, ICG-001 and IWR-1 were used to inhibit the wnt/ $\beta$-catenin pathway. Furthermore, intracellular and mitochondrial ROS levels were evaluated using DCFHDA and MitoSOX, respectively. In vivo, after cisplatin injection, rats were intravenously injected with $\mathrm{CM}$ or BMSCs. Sera and kidney tissues were collected on day 3 after cisplatin injection to evaluate changes in renal function and histology. Western blotting and qRT-PCR were employed to determine the expression of wnt/ $\beta$-catenin pathway-related genes and proteins. Immunohistochemical staining was used to evaluate tubular $\beta$-catenin expression in kidney biopsy from AKI patients. Results: CM protected NRK-52E cells from cisplatin-induced injury by restoring the wnt $4 / \beta$-catenin pathway. In response to ICG-001 and IWR-1, the protective effect of $\mathrm{CM}$ was attenuated, characterized by a decrease in cell proliferation and an increase in cell apoptosis and intracellular and mitochondrial ROS levels. Knockdown of $\beta$-catenin using siRNAs also suppressed the mitochondrial biogenesis regulators PGC- $1 \alpha$, TFAM and NRF-1. In the rat model, CM significantly alleviated renal function and histology associated with tubular injury and upregulated wnt 4 and $\beta$-catenin. However, the renoprotective effect of CM was blocked by ICG-001, characterized by exacerbated renal function, suppressed PGC-1 $\alpha$ expression and increased mitochondrial ROS. Clinical data showed that the tubular $\beta$-catenin
\end{abstract}

Ding Xiaoqiang and Yu Xiaofang
Department of Nephrology, Zhongshan Hospital, Fudan University NO180, Feng'lin Road, Shanghai, 200032 (China)

E-Mail ding.xiaoqiang@zs-hospital.sh.cn, yu.xiaofang@zs-hospital.sh.cn

\section{KARGER}




\section{Cellular Physiology Cell Physiol Biochem 2017;44:1980-1994 \begin{tabular}{l|l|l} 
and Biochemistry 10.1159/000485904 & $\begin{array}{l}\text { C) } 2017 \text { The Author(s). Published by S. Karger AG, Basel } \\
\text { www.karger.com/cpb }\end{array}$ \\
\hline
\end{tabular} \\ Jiao et al.: Activated Wnt/ß-Catenin by BMSCs Ameliorates Acute Kidney Injury}

level was lower in AKI patients experiencing partial recovery than in patients experiencing complete recovery. Conclusion: The activation of the wnt/ $\beta$-catenin pathway by $\mathrm{CM}$ protects against cisplatin-induced kidney injury, resulting in reduced apoptosis and intracellular ROS levels.

\section{Introduction}

Cisplatin is an effective anticancer agent used in the treatment of various solid tumors, including lung, testicular and other cancers. However, toxicity in some organs such as the kidneys limits its use [1]. After being freely filtered through the glomerulus, unbound cisplatin accumulates in renal cells, especially proximal tubular cells. The accumulation of cisplatin leads to nuclear DNA damage, mitochondrial dysfunction, and tubular cell injury, resulting in cell death and causing acute kidney injury (AKI) [2-4].

Mesenchymal stem cells (MSCs) have emerged as a promising mode of therapy for AKI $[5,6]$. MSCs can modulate inflammation and promote the regeneration of injured cells through the secretion of factors rather than by direct engraftment and differentiation [79]. Cell-free therapy is a promising alternative to the direct infusion of MSCs. Some studies have suggested that conditioned medium (CM) from MSCs is beneficial for the repair of organ injury, such as ischemic heart disease [10], diabetic endothelial dysfunction [11], and acute lung injury [12]. However, the effect of CM on cisplatin-induced AKI has not been fully investigated.

Wnt signaling, one of the evolutionarily conserved pathways, is associated with organ development, homeostasis and tissue repair [13-15]. When wnt ligands bind to Frizzled receptors and LRP5/6 coreceptors, the $\beta$-catenin degradation complex is sequestered, leading to the translocation of $\beta$-catenin to the nucleus to prompt the expression of target genes regulating cell fate, proliferation and apoptosis [16-19]. Following AKI, the wnt/ $\beta$ catenin pathway is involved in the repair of renal tubular cells [20-22]. Some studies have also suggested that the Wnt signaling pathway can be regulated by MSCs, and this is associated with the repair process after injury [23, 24].

In this study, we examined the effect of $\mathrm{CM}$ on cisplatin-induced kidney injury and further explored the role of the wnt/ $\beta$-catenin pathway in renoprotection.

\section{Materials and Methods}

Bone Marrow MSC (BMSC) Isolation and CM Preparation

Four-week-old Sprague Dawley (SD) rats were anesthetization, sacrificed and then immersed in $75 \%$ ethanol. Then, BMSCs were isolated from both lower limb femurs of the rats. BMSCs were cultured in medium with $10 \%$ FBS, penicillin and streptomycin.

When BMSCs (passages 5-7) reached $80 \%$ confluence, the medium was replaced with serum-free medium for $48 \mathrm{~h}$. Then, the medium was collected and centrifuged at $3000 \times \mathrm{g}$ for $20 \mathrm{~min}$, and the supernatant was used as CM. For the in vivo experiments, CM was concentrated by centrifugal ultrafilter unit $(10 \mathrm{~K}$; Millipore) according to the manufacturer's instructions.

Cell Culture and Treatment

NRK-52E cells were cultured in DMEM-F12 with 10\% FBS. At 80\% confluence, the cells were treated as follows: control (no treatment), cisplatin (50 $\mathrm{M}$ cisplatin for $12 \mathrm{~h}$ ), CM (only $\mathrm{CM}$ ) and CM+cisplatin (cisplatin treatment with $\mathrm{CM}$ ).

Cell Viability Assay

The Alamar Blue kit (Invitrogen) was used to determine cell viability according to the manufacturer's protocol. Cells were seeded into 96-well plates. After treatment of cisplatin or CM, $10 \mu$ l Alamar Blue solution was added to each well. Then, the plates were incubated at $37^{\circ} \mathrm{C}$ for $4 \mathrm{~h}$, and the absorbance was measured at $570 \mathrm{~nm}$. 


\section{Cellular Physiology Cell Physiol Biochem 2017;44:1980-1994 \begin{tabular}{l|l|l} 
and Biochemistry & DOI: 10.1159/000485904 & $\begin{array}{l}\text { C } 2017 \text { The Author(s). Published by S. Karger AG, Basel } \\
\text { www.karger.com/cpb }\end{array}$
\end{tabular} \\ Jiao et al.: Activated Wnt/ $\beta$-Catenin by BMSCs Ameliorates Acute Kidney Injury}

Cell Apoptosis Assay

Cellular apoptosis was determined using the Annexin V-FITC staining kit (Thermo Fisher Scientific) according to the manufacturer's instructions. The cells were collected and washed after treatment, resuspended in binding buffer and then incubated with Annexin V-FITC for 15 min in the dark. After the addition of propidium iodide (PI), the cells were analyzed by flow cytometry.

\section{Cell Cycle Assay}

After treatment, cells were collected and permeabilized in $70 \%$ ethanol overnight at $4^{\circ} \mathrm{C}$. RNase was added to the cells and incubated at $37^{\circ} \mathrm{C}$ for $30 \mathrm{~min}$. Then, the cells were treated with PI for $30 \mathrm{~min}$ at $4^{\circ} \mathrm{C}$, and flow cytometry was performed to assess cell cycle distribution.

\section{Measurement of Intracellular and Mitochondrial ROS Generation}

Intracellular reactive oxygen species (ROS) were measured by flow cytometry with dichloro-dihydrofluorescein diacetate (DCFH-DA; KeyGen Biotech). After treatment, the cells were washed with PBS and incubated with $10 \mu \mathrm{M}$ DCFH-DA for $20 \mathrm{~min}$ at $37^{\circ} \mathrm{C}$. The collected cells were analyzed using an Attune NxT Flow Cytometer. For the determination of mitochondrial ROS, cells were treated with $5 \mu \mathrm{M}$ MitoSOX RED (Thermo Fisher Scientific) for $10 \mathrm{~min}$ at $37^{\circ} \mathrm{C}$ and then examined with a Leica fluorescence microscope.

\section{Western Blotting}

Proteins were isolated using lysis buffer. Homogenates were separated via $10 \%$ sodium dodecyl-sulfate polyacrylamide gel electrophoresis and transferred to nitrocellulose membranes for antibody probing. After being blocked by $5 \%$ non-fat milk for $1 \mathrm{~h}$ at room temperature, the membranes were incubated with the primary antibodies ( $\beta$-catenin, Cell Signaling Technology; wnt4, Santa Cruz Biotechnology; and PGC-1 $\alpha$, Abcam) overnight at $4^{\circ} \mathrm{C}$. Following treatment with peroxidase-conjugated secondary antibodies, bands were visualized using enhanced chemiluminescence reagents.

\section{RNA Isolation and Real-Time RT-PCR}

Total RNA was isolated using TRI Reagent (Sigma) according to the manufacturer's instructions. Reverse transcription was performed on cDNA using random primers (Takara). SYBR Premix Ex Taq ${ }^{\mathrm{TM}}$ (Takara) was used for quantitative real-time PCR. The 18S rRNA gene was used as a housekeeping gene to normalize gene expression.

\section{Rat AKI Model}

All experiments were performed on 6- to 8-week-old male SD rats obtained from the Animal Center, Shanghai Medical College, Fudan University. The rats were allowed free access to water and food. All protocols were approved by the Institutional Animal Care and Use Committee of Fudan University.

For the AKI model, SD rats were intraperitoneally injected with $7 \mathrm{mg} / \mathrm{kg}$ cisplatin. In the BMSC group, 1 day after cisplatin treatment, the rats were injected with BMSCs via the caudal vein. In the CM group, CM $(2 \mathrm{mg}$ ) was injected daily into the tail vein of rats. To inhibit $\beta$-catenin, ICG-001 was administered intraperitoneally after CM injection. All rats were sacrificed on day 3 post-cisplatin. Each group had 7-8 rats.

\section{Rat Serum Creatinine}

Serum creatinine (Scr) levels were determined using the QuantiChrom ${ }^{\mathrm{TM}}$ Creatinine Assay Kit (BioAssay Systems, Hayward, CA, USA) according to the manufacturer's instructions.

\section{PAS Staining and Histology Scoring}

Kidneys were immersed in 10\% neutral formalin and embedded in paraffin. Periodic acid-Schiff (PAS)-stained $4 \mu \mathrm{m}$-thick renal sections were histopathologically analyzed in a blinded manner. Ten nonoverlapping fields (200x) of the cortex and outer medulla were randomly selected. Then, injury was scored according to the extent of damage to the tubules (loss of brush border, tubular dilation, cast formation, and cell lysis) as follows: (1) <25\% damage; (2) 25-50\% damage; (3) 50-75\% damage; and (4)>75\% damage.

\section{Patient Selection and Renal Immunohistochemistry}

We selected 6 patients with AKI (without pre-existing chronic kidney disease (CKD)) according to the criteria of Scr level recommended in KDIGO [25], and diagnoses of acute tubular necrosis (ATN) were 


\section{Cellular Physiology Cell Physiol Biochem 2017;44:1980-1994

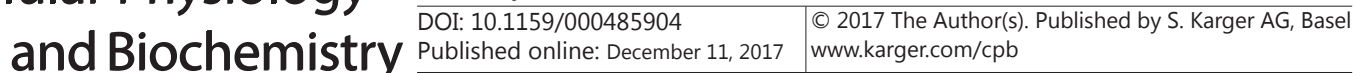 \\ Jiao et al.: Activated Wnt/ $\beta$-Catenin by BMSCs Ameliorates Acute Kidney Injury}

confirmed by renal biopsy. Based on the level of Scr on day 28 after diagnosis, the patients were classified into either the complete recovery or partial recovery group according to the acute dialysis quality initiative (ADQI) [26]. The control group consisted of normal peritumoral tissues obtained from kidney biopsies from patients with renal clear cell carcinoma. The study was approved by the Clinical Research Ethical Committee of Zhongshan Hospital, Fudan University. All patients provided written informed consent.

Protein expression analyzed by immunohistochemistry as previously described [27]. Then, positive staining was scored based on the IOD (integrated optical density).

\section{Statistical Analysis}

All data are expressed as the mean \pm SEM. One-way ANOVA with Tukey's multiple comparison test was used to analyze multiple-groups with a significance cut-off at $<0.05$. All data were analyzed using GraphPad Prism Software.

\section{Results}

CM ameliorated cisplatin-induced injury in NRK-52E cells

Cisplatin induced significant levels of apoptosis in the NRK-52E cells after $12 \mathrm{~h}$ of incubation. Compared with that in the cisplatin group, the proportion of apoptotic cells was decreased in the cisplatin+CM group (Fig. 1(a, b)). Meanwhile, the relative cell viability in the cisplatin+CM group was restored to $0.79 \pm 0.02$, which was higher than that in the cisplatin group (0.64 \pm 0.03 ) (Fig. 1(c)). Furthermore, the cell cycle distribution analysis indicated that the cisplatin-induced G0/G1 cell cycle arrest was blocked by CM treatment (Fig. 1(d)). The proliferation rate of cells $((\mathrm{S}+\mathrm{G} 2 / \mathrm{M}) /(\mathrm{G} 0 / \mathrm{G} 1+\mathrm{S}+\mathrm{G} 2 / \mathrm{M}))$ was also upregulated in the cisplatin+CM group than that in the cisplatin group. (Fig. 1(e)).

\section{CM activated the $\beta$-catenin pathway in NRK-52E cells}

Given the significant role of $\beta$-catenin in kidney development and repair after AKI [15, $20]$, we evaluated the expression of $\beta$-catenin in tubular cells after CM treatment. In the cisplatin group, the protein expression of $\beta$-catenin was significantly lower than that in the control group. However, compared with that in the cisplatin group, the abundance of tubular $\beta$-catenin was increased in the cisplatin $+C M$ group (Fig. 2(a, b)). Meanwhile, the mRNA levels of Cyclin D1, Myc-1 and Annexin 2, which are downstream targets of $\beta$-catenin, were suppressed by cisplatin, and their levels were restored after CM treatment (Fig. 2(c-e)).

\section{Inhibition of $\beta$-catenin reduced the protective effect of $C M$}

To further confirm the role of the Wnt/ $\beta$-catenin pathway in the protective effect of CM against cisplatin-induced injury, we used two wnt pathway inhibitors ICG-001 and IWR1: the former antagonizes Wnt/ $\beta$-catenin/TCF transcription, and the latter inhibits the Wnt/ $\beta$-catenin pathway by stabilizing the $\beta$-catenin degradation complex. The proportion of apoptotic cells was increased with both ICG-001 and IWR-1 relative to that in the cisplatin+CM group (Fig. 3(a, b)). The degree of restoration of cell viability in the cisplatin+CM group was also reduced by ICG-001 and IWR-1 (Fig. 3(c)). Cell proliferation was markedly lower in both the cisplatin+CM+ICG-001 and cisplatin+CM+IWR-1 groups than in the cisplatin+CM group (Fig. 3(d, e)). Therefore, the CM-induced protection against cisplatin-mediated injury was associated with the activation of the $\mathrm{Wnt} / \beta$-catenin pathway.

\section{$\beta$-catenin was activated by wht in tubular cells}

Since CM could induce the Wnt/ $\beta$-catenin pathway, we attempted to identify the isomer of wnt that mediates $\beta$-catenin activation. We investigated the mRNA levels of the wnt family members, including wnt1, wnt2, wnt3a, wnt4, wnt5b, wnt6, wnt7b and wnt10 in NRK-52E cells. Compared to those in the cisplatin group, Wnt 4 and wnt10 were downregulated by cisplatin and then restored by CM treatment (Fig. 4(a)).

Because the level of wnt4 mRNA was much higher than that of wnt10 and because wnt4 has been reported to play a key role in tubulogenesis [28], we further examined wnt4 


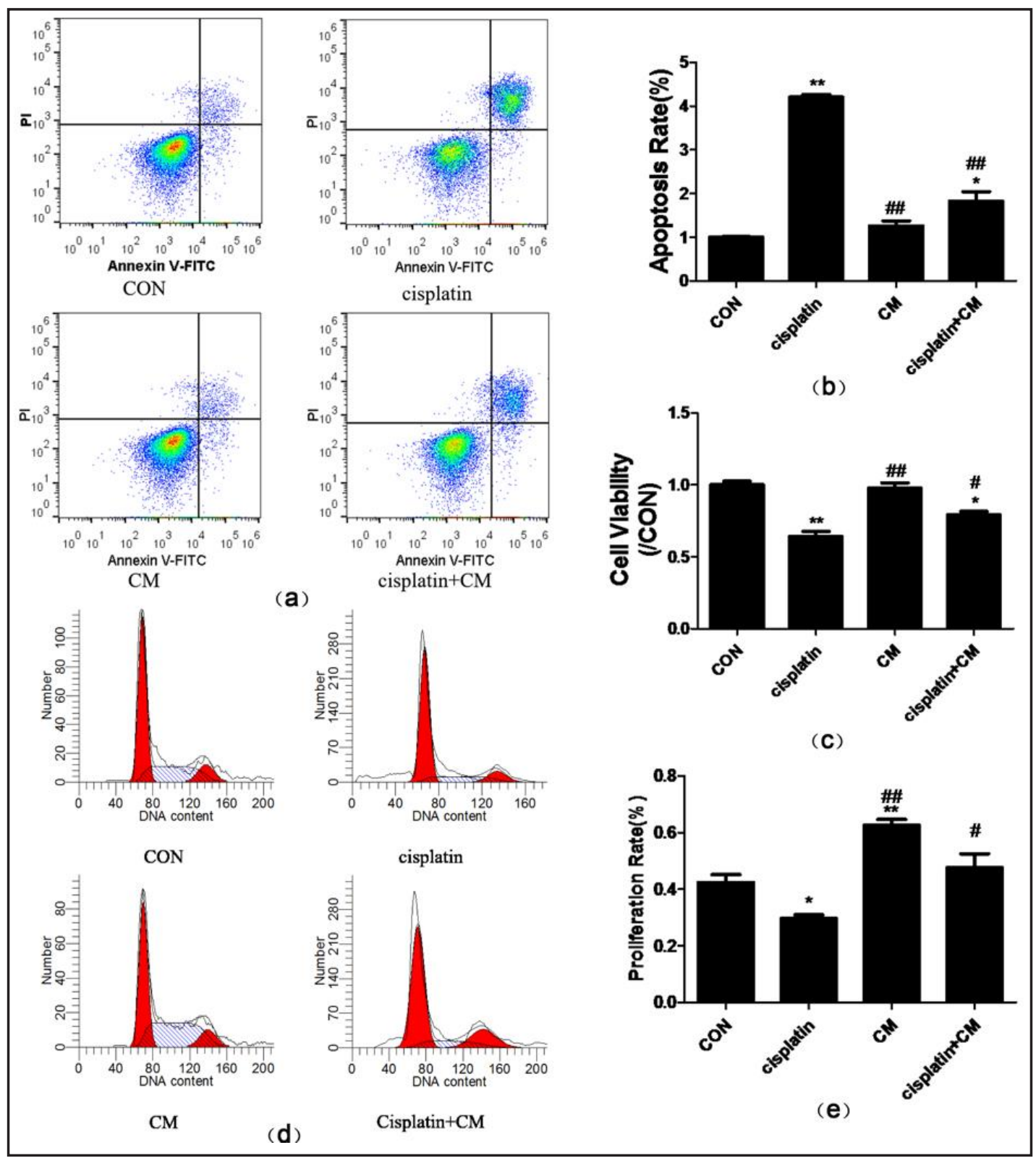

Fig. 1. CM attenuated cisplatin-induced injury in vitro. NRK-52E cells were incubated with cisplatin for 12 $\mathrm{h}$ in the presence or absence of CM. (a) Apoptotic cells were measured using Annexin V/PI dual-staining. (b) Apoptosis rate was determined as the percentage of Annexin V single-positive+Annexin V/PI doublepositive cells. (c) Cell viability was assessed by using Alamar Blue and then quantified using optical density measurements. (d) Cell cycle was assessed by flow cytometry. (e) Percentage of proliferating cells. ${ }^{*} \mathrm{P}<0.05$ versus control $(\mathrm{CON}),{ }^{* *} \mathrm{P}<0.01$ versus $\mathrm{CON}$, ${ }^{\#} \mathrm{P}<0.05$ versus cisplatin, ${ }^{\# \#} \mathrm{P}<0.05$ versus cisplatin, $\mathrm{n}=4$ each.

protein expression by Western blotting. As shown in Fig. 4(b, c), CM restored wnt4 protein expression, which was suppressed by cisplatin. In NRK-52E cells transfected with wnt4siRNA, the expression of $\beta$-catenin protein as well as the mRNA levels of Myc- 1 and Cyclin D1 were lower than those in the negative control cells.

wht/ $\beta$-catenin was involved in the regulation of intracellular and mitochondrial ROS

Oxidative stress plays a significant role in cisplatin-induced tubular injury. After cisplatin treatment, there was a marked elevation of the intracellular and mitochondrial ROS. When 


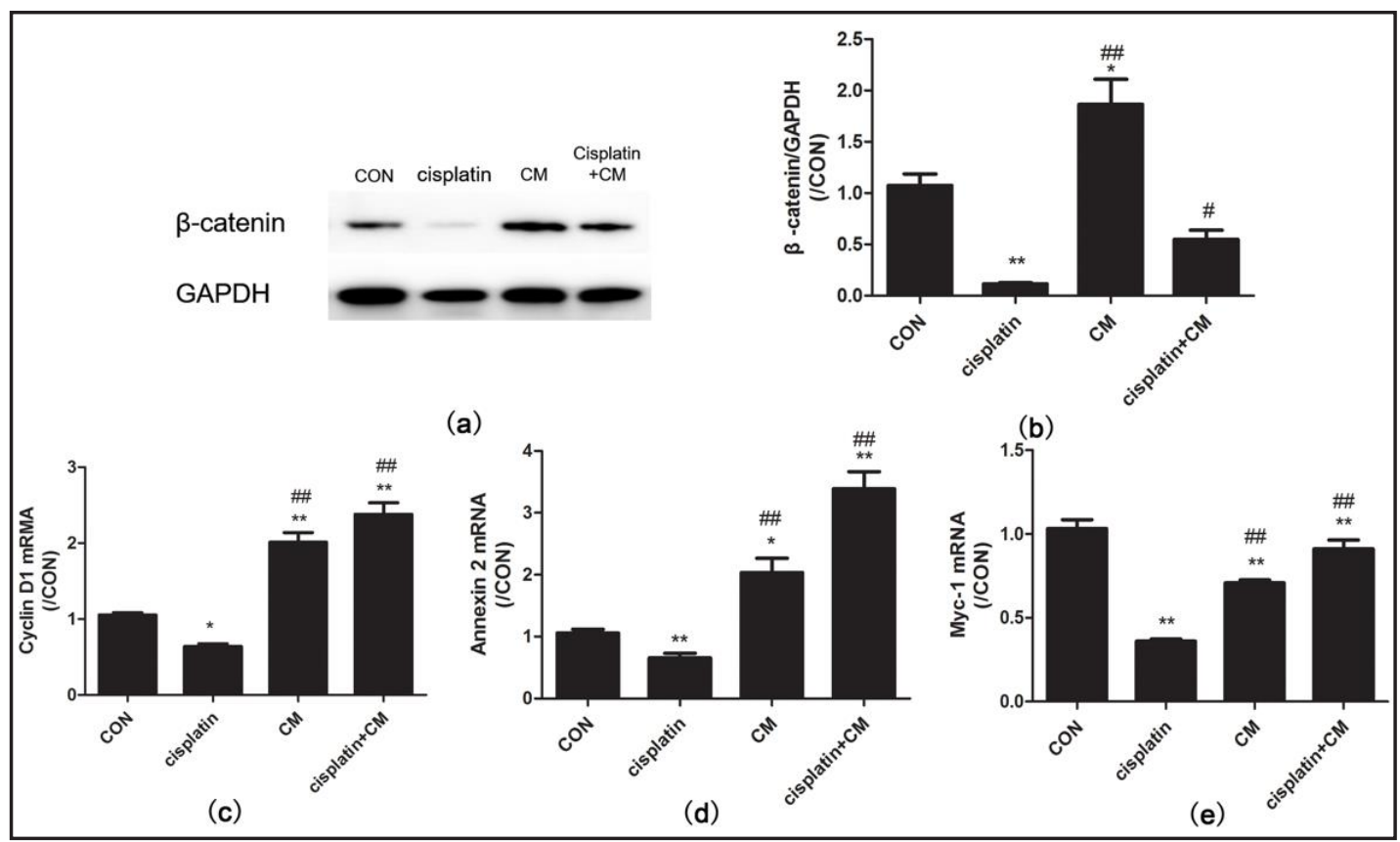

Fig. 2. CM treatment upregulated $\beta$-catenin in NRK-52E cells. Cells were incubated with cisplatin for $12 \mathrm{~h}$ with or without CM. (a) $\beta$-catenin protein expression was analyzed by Western blotting. (b) Relative densitometry based on the ratio of $\beta$-catenin to GAPDH. (c-e) Cyclin D1, Annexin 2 and Myc- 1 mRNA levels were determined by quantitative RT-PCR. Data are expressed as the percentage of control. ${ }^{*} \mathrm{P}<0.05$ versus CON, ${ }^{* *} \mathrm{P}<0.01$ versus $\mathrm{CON},{ }^{\#} \mathrm{P}<0.05$ versus cisplatin, ${ }^{\# \#} \mathrm{P}<0.05$ versus cisplatin, $\mathrm{n}=4$ each.

Fig. 3. Protection of CM against cisplatininduced injury was mediated by the activation of the wnt/ $\beta$-catenin pathway. (a) NRK-52E cells were subjected to flow cytometry to assess apoptosis after incubation with CM in the presence or absence of wnt inhibitors. (b) Quantitative analysis for the percentage of apoptotic cells. (c) Cell viability was quantified using optical density. (d) Cell cycle distribution was analyzed after treatment with $\mathrm{CM}$ in the presence or absence of wnt inhibitors. (e) Percentage of proliferating cells. ${ }^{*} \mathrm{P}<0.05$ versus $\mathrm{CON},{ }^{* *} \mathrm{P}<0.01$

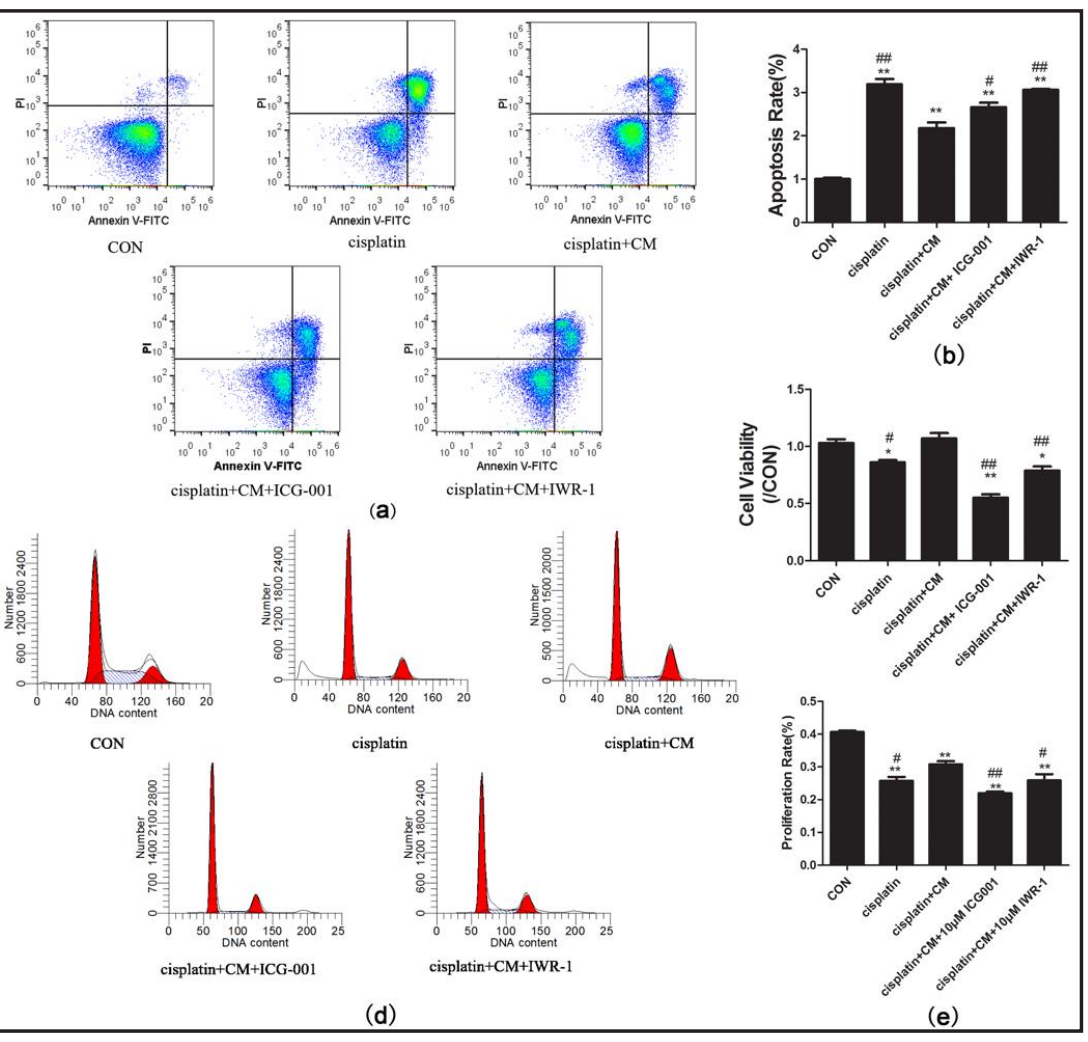

(d)

versus $\mathrm{CON},{ }^{\#} \mathrm{P}<0.05$ versus cisplatin $+\mathrm{CM}$, ${ }^{\# \#} \mathrm{P}<0.01$ versus cisplatin+CM, $\mathrm{n}=6$ each. 


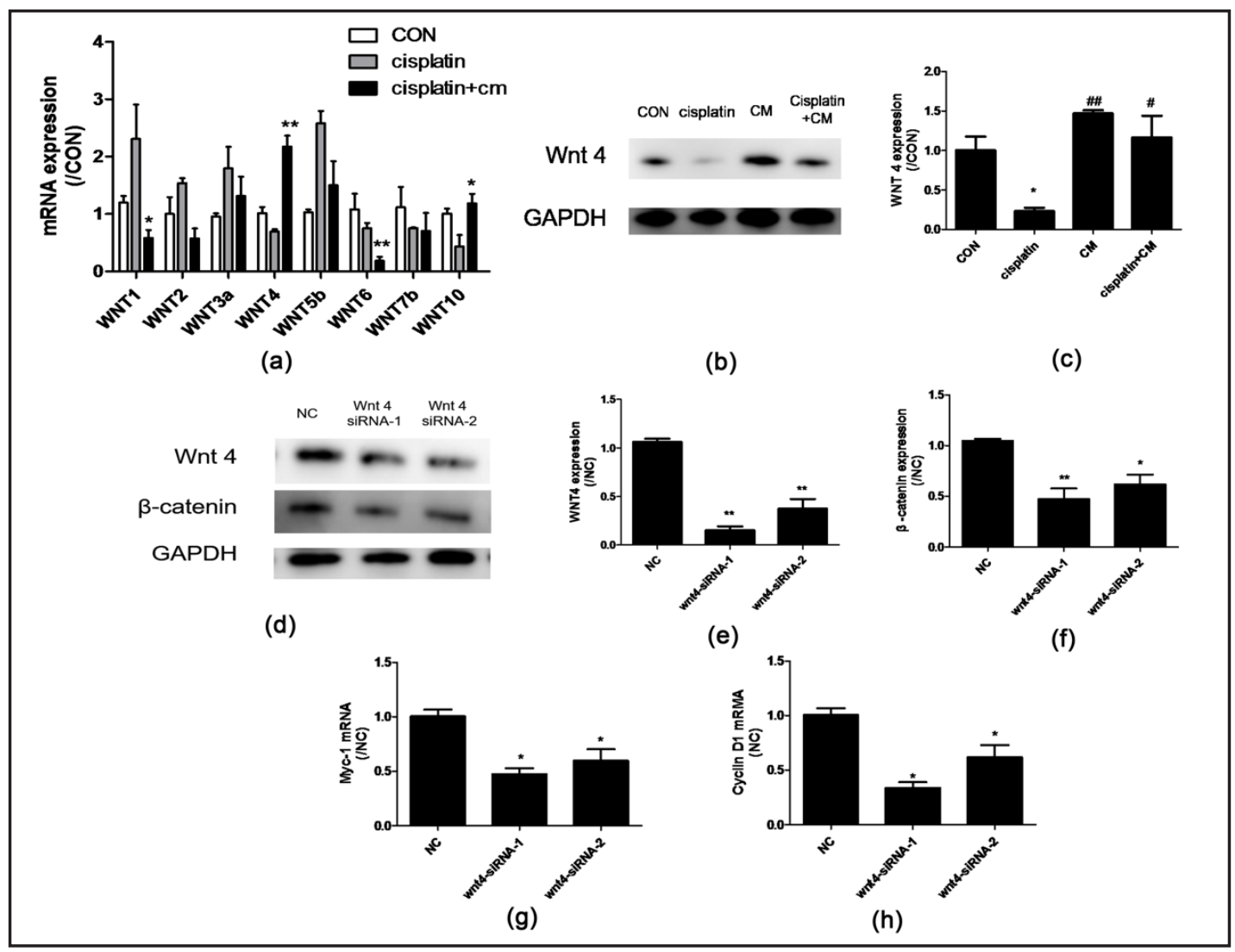

Fig. 4. Activation of $\beta$-catenin by CM treatment upregulated wnt4. (a) mRNA levels of wnt ligands in NRK52E cells were measured by quantitative RT-PCR. (b-c) Protein levels of wnt4 were analyzed by Western blotting with or without CM treatment. (d-f) Western blot assay for the detection of wnt 4 and $\beta$-catenin expression in response to the downregulation of wnt4 via siRNA transfection into cells. (g-h) Quantitative RT-PCR for the determination of Myc- 1 and Cyclin D1 mRNA levels. ${ }^{*} \mathrm{P}<0.05$ versus CON, ${ }^{* *} \mathrm{P}<0.01$ versus CON, ${ }^{~} \mathrm{P}<0.05$ versus cisplatin, ${ }^{\# \#} \mathrm{P}<0.05$ versus cisplatin, $\mathrm{n}=4$ each.

treated with CM, excessive ROS levels were reduced (Fig. 5(a-c)). In addition, the inhibition of the wnt/ $\beta$-catenin pathway by ICG-001 abolished the antioxidative effect of CM(Fig. 5(ac)).

The Wnt/ $\beta$-catenin pathway is also involved in mitochondrial regulation [29]. Therefore, we further determined the expression of PGC- $1 \alpha$, a key regulator of mitochondrial biogenesis, which maintains mitochondrial oxidative balance. After transfection with $\beta$-catenin-siRNA or control-siRNA, NRK-52E cells were incubated with cisplatin+CM. As shown in Fig. 6(ac), PGC- $1 \alpha$ protein expression was reduced in the cells transfected with $\beta$-catenin-siRNA compared to that in the negative control-transfected cells. In addition, the downstream effectors of PGC- $1 \alpha$, including mitochondrial transcription factor A (TFAM) and nuclear respiratory factor 1 (NRF-1) were also reduced in response to the downregulation of $\beta$-catenin via siRNA (Fig. 6(d-e)).

CM decreased cisplatin-induced kidney injury and activated the wnt/ $\beta$-catenin pathway in rats

We next use a cisplatin-induced rat kidney injury model to further investigate the role of the wnt $\beta$-catenin pathway in the renoprotective effect of CM. Similar to BMSC treatment, CM administration ameliorated cisplatin-induced injury to rat kidneys, characterized by decreased Scr levels (Fig. 7(c)) and improved tubular cell morphology (Fig. 7(a-b)). Compared with cisplatin alone, both CM and BMSCs restored wnt 4 and $\beta$-catenin expression

\section{KARGER}




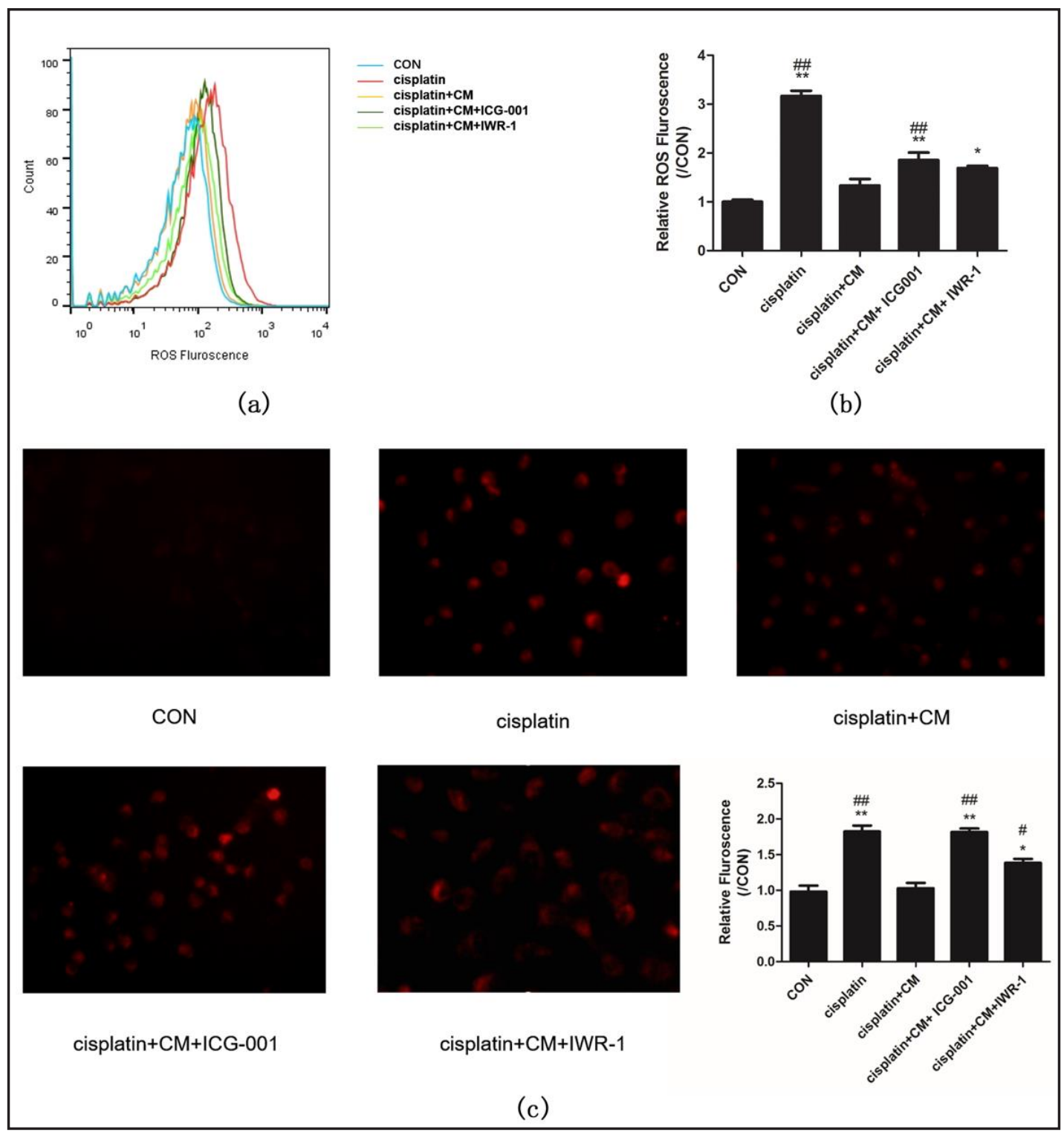

Fig. 5. Inhibition of the wnt/ $\beta$-catenin pathway reversed excessive ROS. (a-b) Intracellular ROS levels were determined using DCFH-DA for 20 min after incubation with the indicated inhibitors. (c) Mitochondrial ROS exhibited red fluorescence detected by MitoSOX. ${ }^{*} \mathrm{P}<0.05$ versus $\mathrm{CON},{ }^{*} \mathrm{P}<0.01$ versus $\mathrm{CON}$, ${ }^{*} \mathrm{P}<0.05$ versus cisplatin+CM, ${ }^{\# \#} \mathrm{P}<0.01$ versus cisplatin+CM, $\mathrm{n}=4$ each.

in the kidney tissues (Fig. 7(d-f)) as well as the mRNA levels of Cyclin D1 and Myc-1 (Fig. 7(gh)). Therefore, CM exerted a similar effect as that of BMSCs in ameliorating cisplatin-induced kidney injury.

Inhibition of wnt/ $\beta$-catenin ameliorated the renoprotective effect of CM and increased the production of mitochondrial ROS

To confirm the role of the wnt/ $\beta$-catenin pathway in the renoprotective effect of $\mathrm{CM}$ in vivo, we treated the rats with ICG-001 after CM administration. ICG-001 attenuated the protective effect of $\mathrm{CM}$ against cisplatin-induced injury, characterized by augmented impairment of renal function and pathological damage (Fig. 8(a-c)). Meanwhile, PGC-1 $\alpha$ expression was repressed by cisplatin, which was reversed in the cisplatin+CM+DMSO group (Fig. 8(d,e)). In response to suppression of the wnt/ $\beta$-catenin pathway by ICG-001, PGC-

\section{KARGER}




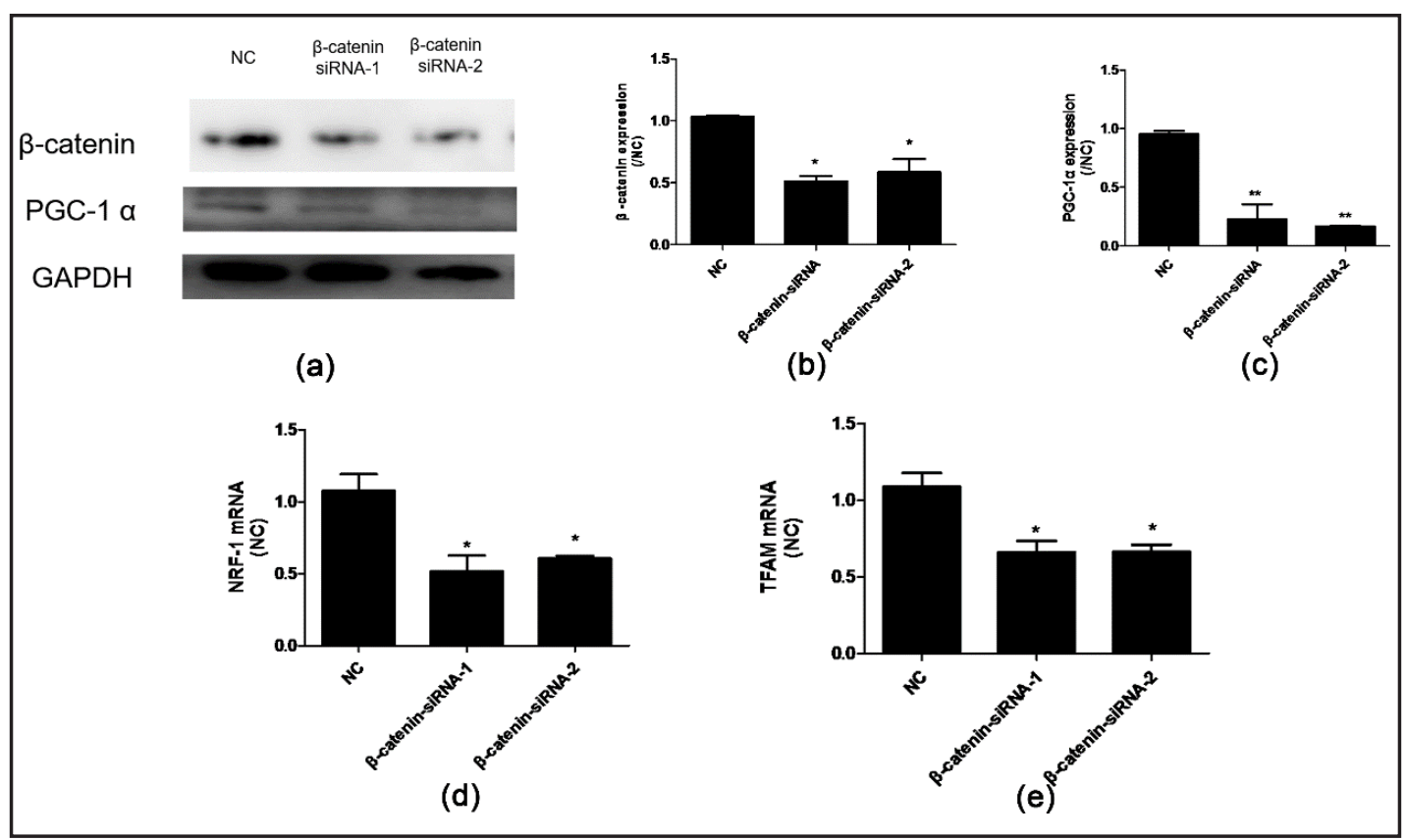

Fig. 6. Inhibition of $\beta$-catenin downregulated the mitochondrial biogenesis regulator PGC-1 $\alpha$. (a) Western blot assay for $\beta$-catenin and PGC- $1 \alpha$ expression. (b-c) Relative densitometry based on the ratio of $\beta$-catenin and PGC- $1 \alpha$ to GAPDH. (d-e) mRNA levels of TFAM and NRF-1 by quantitative RT-PCR. *P<0.05 versus NC, $* * \mathrm{P}<0.01$ versus NC.

$1 \alpha$ protein expression was downregulated (Fig. 8(d,e)), and mitochondrial ROS levels were also increased (Fig. 8(f)). Therefore, the renoprotective effect of CM was associated with the activated wnt/ $\beta$-catenin pathway, accompanied by a reduction in mitochondrial ROS levels.

Tubular $\beta$-catenin expression was associated with the prognosis of patients after AKI

We have demonstrated that the wnt/ $\beta$-catenin pathway contributes to the renal protection of CM against cisplatin-induced AKI. Therefore, we further determined whether the tubular expression of $\beta$-catenin in patients with AKI may be associated with prognosis.

We performed immunohistochemical staining for $\beta$-catenin in kidney biopsies of patients diagnosed with AKI (pathological diagnosis as ATN). However, there was no significant difference in the tubular $\beta$-catenin levels between samples from patients who experienced complete recovery and the control samples. Meanwhile, the expression of $\beta$-catenin was much lower in the patients who experienced partial recovery than in the patients who experienced complete recovery (Fig. 9(a-b)). However, the Scr levels (estimated at the time of kidney biopsy) of patients in both groups were not significantly different. Therefore, $\beta$-catenin expression may be associated with tubular repair after injury.

\section{Discussion}

Studies have indicated that MSC therapy can attenuate AKI via the secretion of paracrine factors $[9,30]$. It has also been shown that CM treatment in cell-free therapy exerts similar renoprotective effects as those of MSCs [30, 31]. However, the underlying molecular mechanism by which CM protects against AKI is unknown. In the present study, we found that similar to BMSCs, CM attenuated cisplatin-induced kidney injury in rats. Furthermore, the activation of the wnt $4 / \beta$-catenin pathway in tubular cells by CM ameliorated cell injury by decreasing apoptosis and inhibiting mitochondrial ROS.

The wnt/ $\beta$-catenin pathway is essential for renal development and is altered after various insults to kidney $[32,33]$. After renal ischemia-reperfusion injury (IRI), the 


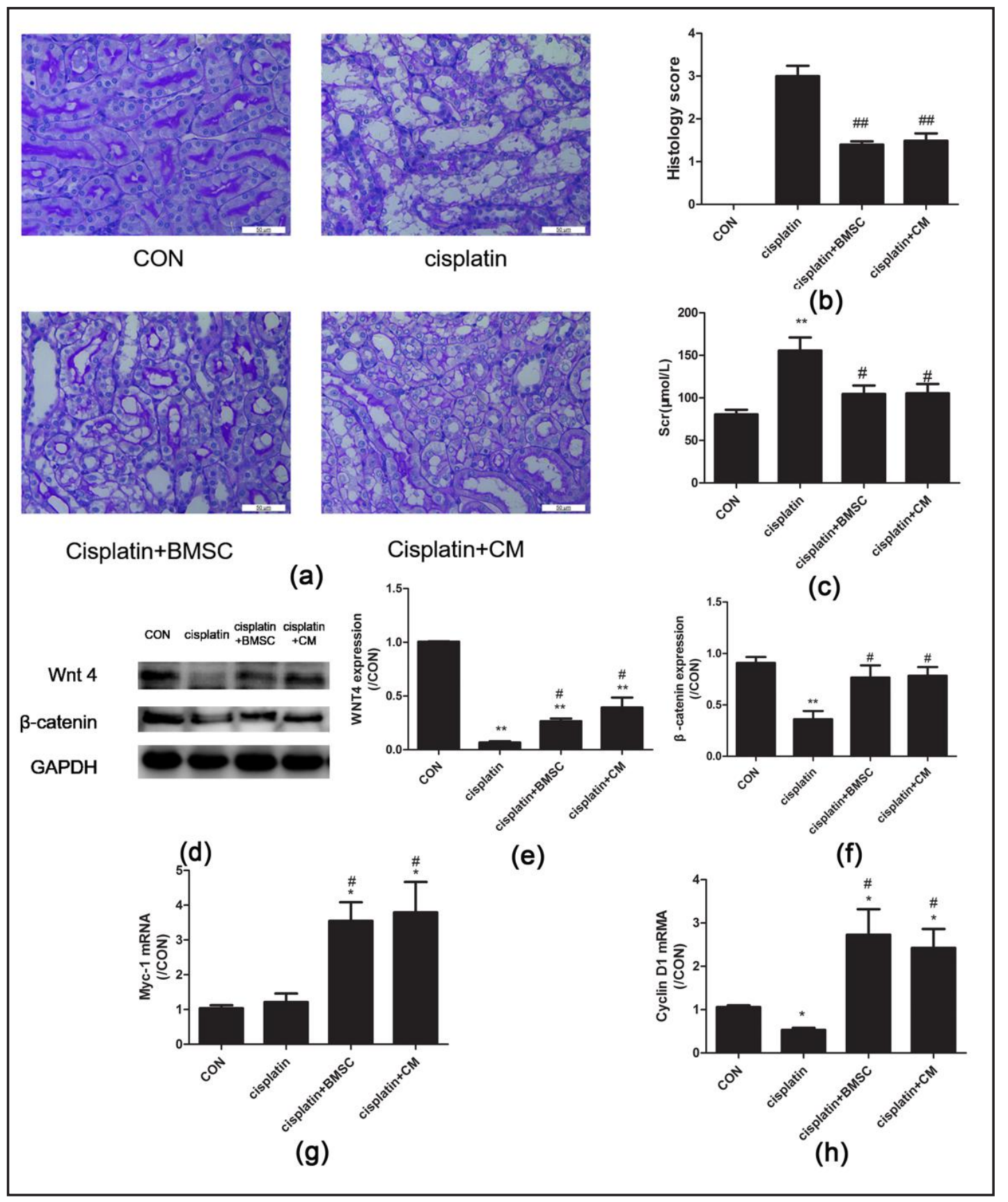

Fig. 7. BMSCs and CM ameliorated cisplatin-induced rat kidney injury with the activation of the wnt/ $\beta$ catenin pathway. (a) Representative PAS-stained kidney sections (magnification 400x) of rats receiving cisplatin in the presence of BMSCs or CM. (b) Semiquantitative histomorphological scoring of PAS-stained sections. (c) Scr level was determined at $72 \mathrm{~h}$ after cisplatin injection. (d) Expression of wnt 4 and $\beta$-catenin in rat kidney lysates was measured by Western blotting and (e-f) analyzed via densitometry. (g-h) Myc-1 and Cyclin D1 mRNA levels were determined by RT-PCR. ${ }^{*} \mathrm{P}<0.05$ versus $\mathrm{CON}$, ${ }^{* *} \mathrm{P}<0.01$ versus CON, $\mathrm{P}<0.05$ versus cisplatin, ${ }^{\# \#} \mathrm{P}<0.01$ versus cisplatin, $\mathrm{n}=6$ each.

wnt/ $\beta$-catenin pathway is reactivated and induces the repair process after injury [21, 32]. In response to a wnt agonist, renal IRI is mitigated, and regeneration of tubular cells is prompted, characterized by reduced inflammation and oxidative stress [22]. In the clinical samples, $\beta$-catenin was expressed in renal tubular cells from both the AKI group 


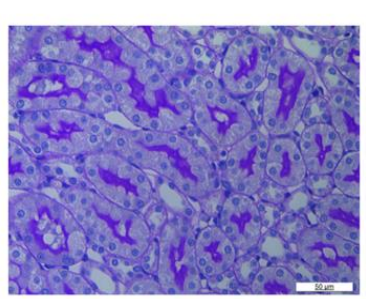

CON

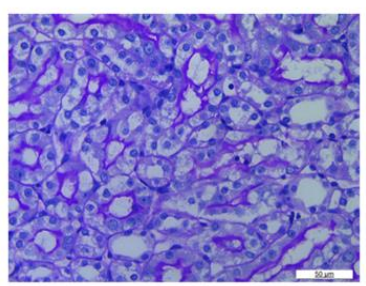

Cisplatin+CM+DMSO

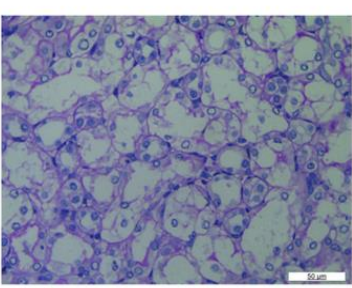

cisplatin

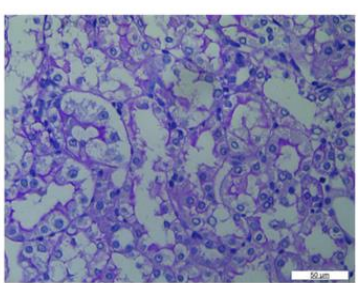

Cisplatin+CM+DMSO+ICG-001

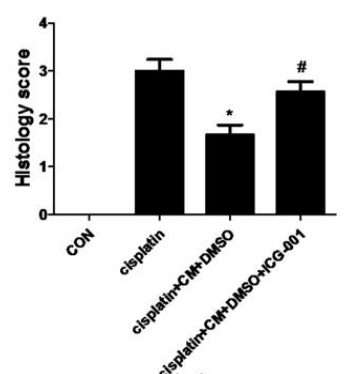

(b)

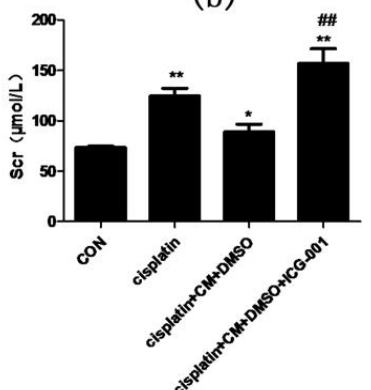

(c)

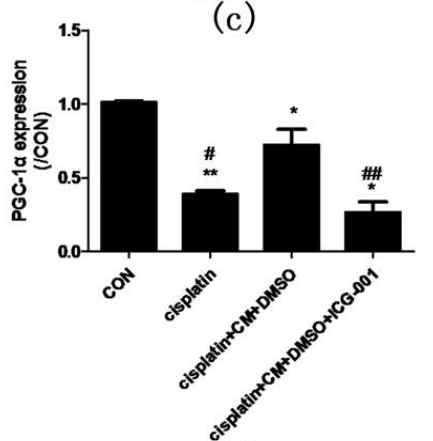

(e)
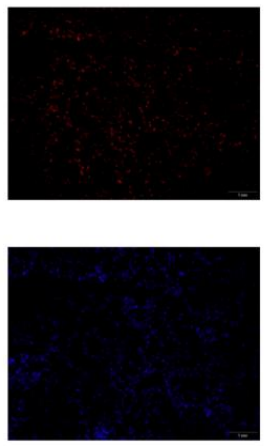

Cisplatin+CM+DMSO +ICG-001

Fig. 8. Inhibition of the wnt/ $\beta$-catenin pathway ameliorated the protective effect of CM. (a) Kidney sections of rats were stained with PAS (magnification 400x). (b) Semiquantitative histomorphological scoring of PASstained sections. (c) Scr level was determined at $72 \mathrm{~h}$ after cisplatin injection. (d-e) Western blotting and semiquantitative densitometry analysis of PGC-1 $\alpha$ expression. (f) Representative red immunofluorescence labeling of mitochondrial ROS in kidney sections. ${ }^{*} \mathrm{P}<0.05$ versus $\mathrm{CON},{ }^{* *} \mathrm{P}<0.01$ versus $\mathrm{CON}$, ${ }^{*} \mathrm{P}<0.05$ versus cisplatin+CM+DMSO, ${ }^{\# \#} \mathrm{P}<0.01$ versus cisplatin+CM+DMSO, $\mathrm{n}=6$ each. 


\section{Cellular Physiology and Biochemistry \begin{tabular}{l|l} 
DOI: 10.1159/000485904 & (c) 2017 The Author(s). Published by S. Karger AG, Basel \\
www.karger.com/cpb
\end{tabular} \\ Jiao et al.: Activated Wnt/ $\beta$-Catenin by BMSCs Ameliorates Acute Kidney Injury}

Fig. 9. Tubular $\beta$-catenin expression was associated with renal recovery of AKI patients at 28 days. (a) Immunohistochemical analysis of $\beta$-catenin levels in the kidneys of AKI patients with complete or partial recovery. (b) Histogram showing the relative $\beta$-catenin protein expression. (c) Scr levels of AKI patients when undergoing renal biopsy. ${ }^{*} \mathrm{P}<0.05$ versus CON, ${ }^{\#} \mathrm{P}<0.01$ versus complete recovery. $n=3$ each.

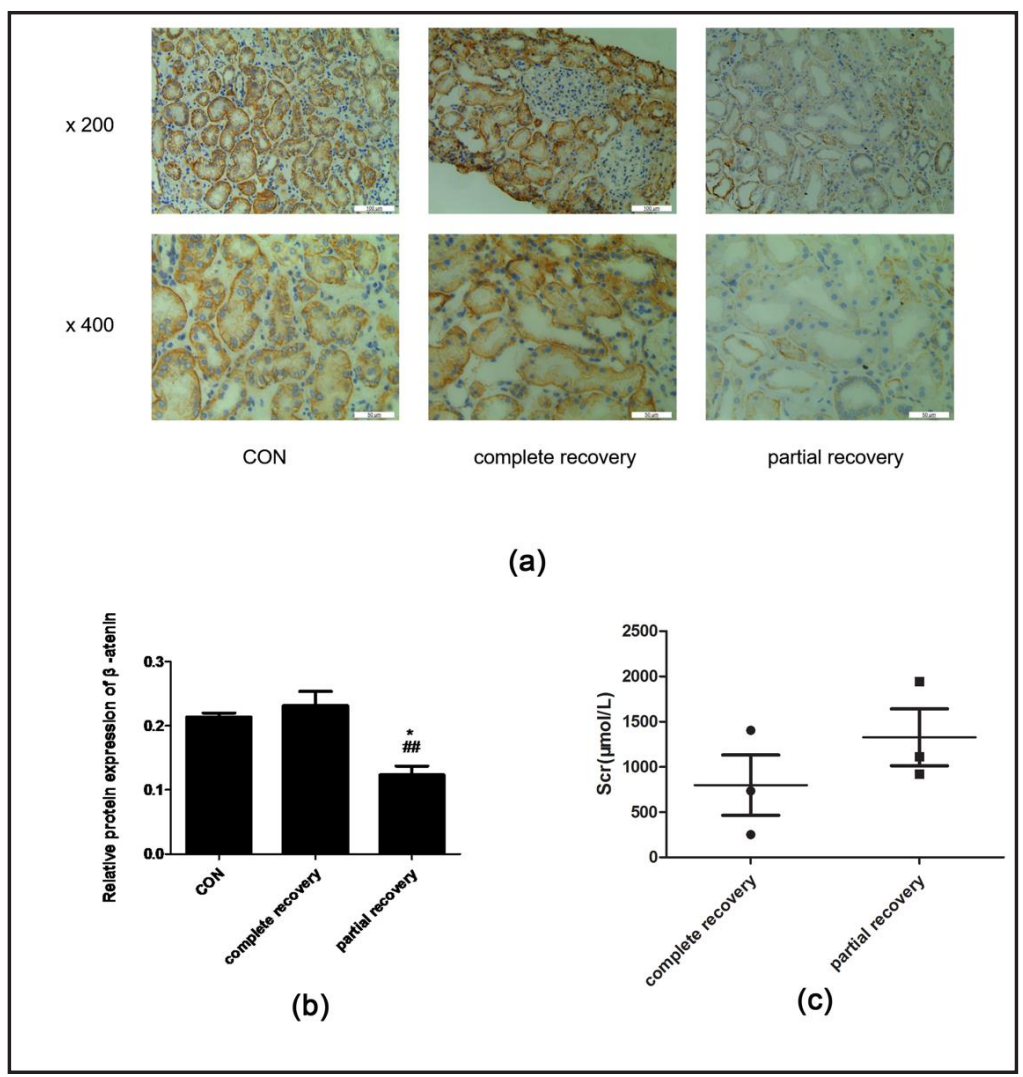

and the control groups. However, tubular $\beta$-catenin expression was higher in AKI patients who experienced complete recovery at 28 days than in patients who experienced partial recovery. This suggests that tubular $\beta$-catenin expression is associated with kidney repair. However, we found that in response to cisplatin-induced injury, $\beta$-catenin expression was reduced with an increase in apoptosis and a decrease in proliferation in NRK-52E cells. In the presence of $\mathrm{CM}$, tubular $\beta$-catenin expression was restored accompanied with a decreased in cell apoptosis and an increase in cell proliferation. In addition, the downstream effectors of $\beta$-catenin, including Myc-1, Cyclin D1 and Annexin 2, were upregulated. Some studies have shown that with the specific depletion of $\beta$-catenin in the renal tubule, apoptosis is aggravated in kidneys [20]. When cells were treated with the wnt/ $\beta$-catenin inhibitors ICG001 and IWR-1 in vitro, the protective effect of CM was ameliorated. In the rat model, CM attenuated cisplatin-induced injury by restoring $\beta$-catenin expression and the mRNA levels of Myc-1 and Cyclin D1. Furthermore, this renoprotective effect was ameliorated by ICG-001. This indicated that $\beta$-catenin is activated by CM against cisplatin-induced injury.

As a downstream effector of the canonical wnt pathway, $\beta$-catenin can be activated by different wnt isoforms. It has been shown that wnt7b produced by macrophages can promote tubular repair by activating the canonical wnt pathway in the proximal tubular cells [34]. To determine the wnt isoform that was involved in mediating the protective effect of CM, we assessed the mRNA levels of wnt 1 , wnt2, wnt3a, wnt4, wnt5b, wnt6, wnt7b and wnt10 in NRK-52E cells. In response to cisplatin, only wnt 4 and wnt10 levels were restored by CM treatment, with wnt4 being more strongly affected than wnt10. It has been reported that Wnt4 plays a key role in kidney tubulogenesis $[28,35]$. In addition, in the early phase of renal IRI, wnt4 is localized near the site of tubule regeneration, and it is involved in the regulation of $\beta$-catenin/Cyclin D1 [21]. In our study, CM restored tubular wnt4 protein expression both in vitro and in vivo. Transfection of NRK-52E cells with wnt4-siRNA downregulated $\beta$-catenin expression and decreased the mRNA levels of Myc-1 and Cyclin D1. Thus, CM could restore the wnt $4 / \beta$-catenin pathway in tubules to attenuate cisplatin-mediated injury. 


\section{Cellular Physiology Cell Physiol Biochem 2017;44:1980-1994 \begin{tabular}{ll|l} 
DOI: 10.1159/000485904 & $\begin{array}{l}\text { O 2017 The Author(s). Published by S. Karger AG, Basel } \\
\text { www.karger.com/cpb }\end{array}$ \\
\hline and Biochemistry Published online: December 11, 2017
\end{tabular}

Redox imbalance plays a significant role in cisplatin-induced injury to kidneys. The mitochondria are the main energy-producing organelles and the major intracellular source of ROS. During acute cellular injury, excess ROS are released by damaged mitochondria, which augments injury even further [36, 37]. Reduction in ROS by mitochondria-targeted antioxidants can ameliorate cisplatin-induced kidney injury [37]. In our study, intracellular and mitochondrial ROS were elevated in NRK-52E cells after incubation with cisplatin. Moreover, when the cells were treated with CM, the intracellular and mitochondrial ROS were reduced. Several studies in the literature have reported that the depletion of $\beta$-catenin aggravates oxidative stress $[38,39]$. We also found that the inhibition of the wnt/ $\beta$-catenin pathway in NRK-52E cells by ICG-001 negated the CM-mediated suppression of excessive ROS. This was also confirmed in our rat model, indicating that mitochondrial ROS were involved in the wnt $/ \beta$-catenin pathways regulated by $\mathrm{CM}$.

PGC-1 $\alpha$, a transcriptional coactivator, can interact with NRF-1 and regulate TFAM to prompt mitochondrial biogenesis and maintain mitochondrial redox balance [40]. Therefore, the activation or overexpression of PGC- $1 \alpha$ can attenuate AKI and prompt the renal recovery $[41,42]$. Recently, some studies have shown that the wnt pathway regulates mitochondrial function $[29,43]$. The overexpression of wnt1 in the hepatocytes of mice demonstrated an overall decrease in ROS levels accompanied with the nuclear accumulation of PGC- $1 \alpha$ and p-Sirt1 [44]. In our study, when $\beta$-catenin was depleted in NRK-52E cells via siRNAs, PGC- $1 \alpha$, TAFM and NRF- 1 were inhibited. In the rat model, CM restored PGC- $1 \alpha$ expression, which has been suppressed by cisplatin. Similarly, inhibition of the wnt/ $\beta$-catenin pathway downregulated PGC- $1 \alpha$. Therefore, the wnt/ $\beta$-catenin pathway regulates mitochondrial ROS via PGC- $1 \alpha$.

\section{Conclusion}

We uncovered the underlying molecular mechanism associated with the renoprotective effect $\mathrm{CM}$ against cisplatin-induced injury and found it to be mediated by the activation of the wnt/ $\beta$-catenin pathway, the suppression of excessive cellular ROS and the reduction in tubular apoptosis. However, additional clinical studies are necessary to confirm the effect of $\mathrm{CM}$ as a potential therapeutic agent for AKI patients.

\section{Disclosure Statement}

The authors declare they have no conflicts of interest to disclose.

\section{Acknowledgements}

This work was supported by Grants 81570600, 81600517 and 81430015 from the National Natural Science Foundation of China and 15YF1402100 from Shanghai Sailing Plan.

\section{References}

$>1$ Jaiman S, Sharma AK, Singh K, Khanna D: Signalling mechanisms involved in renal pathological changes during cisplatin-induced nephropathy. Eur J Clin Pharmacol 2013;69:1863-1874.

-2 Xu Y, Ma H, Shao J, Wu J, Zhou L, Zhang Z, Wang Y, Huang Z, Ren J, Liu S, Chen X, Han J: A Role for Tubular Necroptosis in Cisplatin-Induced AKI. J Am Soc Nephrol 2015;26:2647-2658.

-3 Marullo R, Werner E, Degtyareva N, Moore B, Altavilla G, Ramalingam SS, Doetsch PW: Cisplatin induces a mitochondrial-ROS response that contributes to cytotoxicity depending on mitochondrial redox status and bioenergetic functions. PLoS One 2013;8:e81162.

- 4 Oh CJ, Ha CM, Choi YK, Park S, Choe MS, Jeoung NH, Huh YH, Kim HJ, Kweon HS, Lee JM, Lee SJ, Jeon JH, Harris RA, Park KG, Lee IK: Pyruvate dehydrogenase kinase 4 deficiency attenuates cisplatin-induced acute kidney injury. Kidney Int 2017;91:880-895. 


\section{Cellular Physiology Cell Physiol Biochem 2017;44:1980-1994 \begin{tabular}{l|l|l} 
and Biochemistry & DOI: 10.1159/000485904 & $\begin{array}{l}\text { (c) } 2017 \text { The Author(s). Published by S. Karger AG, Basel } \\
\text { www.karger.com/cpb }\end{array}$
\end{tabular}

5 Park JH, Jang HR, Kim DH, Kwon GY, Lee JE, Huh W, Choi SJ, Oh W, Oh HY, Kim YG: Early, but not late treatment with human umbilical cord blood-derived mesenchymal stem cells attenuates cisplatin nephrotoxicity through immunomodulation. Am J Physiol Renal Physiol 2017:13:F984-996.

6 Zhu Y, Yu J, Yin L, Zhou Y, Sun Z, Jia H, Tao Y, Liu W, Zhang B, Zhang J, Wang M, Zhang X, Yan Y, Xue J, Gu H, Mao F, Xu W, Qian H: MicroRNA-146b, a Sensitive Indicator of Mesenchymal Stem Cell Repair of Acute Renal Injury. Stem Cells Transl Med 2016;5:1406-1415.

7 Duffield JS, Park KM, Hsiao LL, Kelley VR, Scadden DT, Ichimura T, Bonventre JV: Restoration of tubular epithelial cells during repair of the postischemic kidney occurs independently of bone marrow-derived stem cells. J Clin Invest 2005;115:1743-1755.

-8 Moghadasali R, Mutsaers HA, Azarnia M, Aghdami N, Baharvand H, Torensma R, Wilmer MJ, Masereeuw R: Mesenchymal stem cell-conditioned medium accelerates regeneration of human renal proximal tubule epithelial cells after gentamicin toxicity. Exp Toxicol Pathol 2013;65:595-600.

-9 Erpicum P, Detry O, Weekers L, Bonvoisin C, Lechanteur C, Briquet A, Beguin Y, Krzesinski JM, Jouret F: Mesenchymal stromal cell therapy in conditions of renal ischaemia/reperfusion. Nephrol Dial Transplant 2014;29:1487-1493.

10 Timmers L, Lim SK, Hoefer IE, Arslan F, Lai RC, van Oorschot AA, Goumans MJ, Strijder C, Sze SK, Choo A, Piek JJ, Doevendans PA, Pasterkamp G, de Kleijn DP: Human mesenchymal stem cell-conditioned medium improves cardiac function following myocardial infarction. Stem Cell Res 2011;6:206-214.

11 Yuan YJ, Shi MM, Li L, Liu JP, Chen B, Chen YN, An XX, Liu SY, Luo RX, Long D, Zhang WG, Newsholme P, Cheng JQ, Lu YR: Mesenchymal stem cell-conditioned media ameliorate diabetic endothelial dysfunction by improving mitochondrial bioenergetics via the Sirt1/AMPK/PGC-1 alpha pathway. Clin Sci 2016;130:21812198.

12 Ionescu L, Byrne RN, van Haaften T, Vadivel A, Alphonse RS, Rey-Parra GJ, Weissmann G, Hall A, Eaton F, Thebaud B: Stem cell conditioned medium improves acute lung injury in mice: in vivo evidence for stem cell paracrine action. Am J Physiol Lung Cell Mol Physiol 2012;303:L967-977.

13 Deb A: Cell-cell interaction in the heart via Wnt/beta-catenin pathway after cardiac injury. Cardiovasc Res 2014;102:214-223.

14 Lim X, Nusse R: Wnt signaling in skin development, homeostasis, and disease. Cold Spring Harb Perspect Biol 2013;5.

15 Zhou D, Tan RJ, Fu H, Liu Y: Wnt/beta-catenin signaling in kidney injury and repair: a double-edged sword. Lab Invest 2016;96:156-167.

16 Merkel CE, Karner CM, Carroll TJ: Molecular regulation of kidney development: is the answer blowing in the Wnt? Pediatr Nephrol 2007;22:1825-1838.

17 Yang Y, Mallampati S, Sun B, Zhang J, Kim SB, Lee JS, Gong Y, Cai Z, Sun X: Wnt pathway contributes to the protection by bone marrow stromal cells of acute lymphoblastic leukemia cells and is a potential therapeutic target. Cancer Lett 2013;333:9-17.

18 Oh SH, Kim HN, Park HJ, Shin JY, Lee PH: Mesenchymal Stem Cells Increase Hippocampal Neurogenesis and Neuronal Differentiation by Enhancing the Wnt Signaling Pathway in an Alzheimer's Disease Model. Cell Transplant 2015;24:1097-1109.

19 Bastakoty D, Young PP: Wnt/beta-catenin pathway in tissue injury: roles in pathology and therapeutic opportunities for regeneration. FASEB J 2016;30:3271-3284.

20 Zhou D, Li Y, Lin L, Zhou L, Igarashi P, Liu Y: Tubule-specific ablation of endogenous beta-catenin aggravates acute kidney injury in mice. Kidney Int 2012;82:537-547.

21 Terada Y, Tanaka H, Okado T, Shimamura H, Inoshita S, Kuwahara M, Sasaki S: Expression and function of the developmental gene Wnt-4 during experimental acute renal failure in rats. J Am Soc Nephrol 2003;14:1223-1233.

22 Kuncewitch M, Yang WL, Corbo L, Khader A, Nicastro J, Coppa GF, Wang P: WNT Agonist Decreases Tissue Damage and Improves Renal Function After Ischemia-Reperfusion. Shock 2015;43:268-275.

-23 Zhang B, Wu X, Zhang X, Sun Y, Yan Y, Shi H, Zhu Y, Wu L, Pan Z, Zhu W, Qian H, Xu W: Human umbilical cord mesenchymal stem cell exosomes enhance angiogenesis through the Wnt4/beta-catenin pathway. Stem Cells Transl Med 2015;4:513-522.

24 Zhang B, Wang M, Gong A, Zhang X, Wu X, Zhu Y, Shi H, Wu L, Zhu W, Qian H, Xu W: HucMSC-Exosome Mediated-Wnt4 Signaling Is Required for Cutaneous Wound Healing. Stem Cells 2015;33:2158-2168. 


\section{Cellular Physiology Cell Physiol Biochem 2017;44:1980-1994 \begin{tabular}{l|l|l} 
and Biochemistry & DOI: 10.1159/000485904 2017 The Author(s). Published by S. Karger AG, Basel \\
www.karger.com/cpb
\end{tabular}

25 Kellum JA, Lameire N, Group KAGW: Diagnosis, evaluation, and management of acute kidney injury: a KDIGO summary (Part 1). Crit Care 2013;17:204.

26 Kellum JA: How can we define recovery after acute kidney injury? Considerations from epidemiology and clinical trial design. Nephron Clin Pract 2014;127:81-88.

27 Zhao SL, Wei SY, Wang YX, Diao TT, Li JS, He YX, Yu J, Jiang XY, Cao Y, Mao XY, Wei QJ, Wang Y, Li B: Wnt4 is a novel biomarker for the early detection of kidney tubular injury after ischemia/reperfusion injury. Sci Rep 2016;6:32610.

-28 Kispert A, Vainio S, McMahon AP: Wnt-4 is a mesenchymal signal for epithelial transformation of metanephric mesenchyme in the developing kidney. Development 1998;125:4225-4234.

29 Lehwald N, Tao GZ, Jang KY, Papandreou I, Liu B, Liu B, Pysz MA, Willmann JK, Knoefel WT, Denko NC, Sylvester KG: beta-Catenin regulates hepatic mitochondrial function and energy balance in mice. Gastroenterology 2012;143:754-764.

-30 Zarjou A, Kim J, Traylor AM, Sanders PW, Balla J, Agarwal A, Curtis LM: Paracrine effects of mesenchymal stem cells in cisplatin-induced renal injury require heme oxygenase-1. Am J Physiol Renal Physiol 2011;300:F254-262.

-31 Reis LA, Borges FT, Simoes MJ, Borges AA, Sinigaglia-Coimbra R, Schor N: Bone marrow-derived mesenchymal stem cells repaired but did not prevent gentamicin-induced acute kidney injury through paracrine effects in rats. PLoS One 2012;7:e44092.

-32 Xiao L, Zhou D, Tan RJ, Fu H, Zhou L, Hou FF, Liu Y: Sustained Activation of Wnt/beta-Catenin Signaling Drives AKI to CKD Progression. J Am Soc Nephrol 2016;27:1727-1740.

33 Wong DW, Yiu WH, Wu HJ, Li RX, Liu Y, Chan KW, Leung JC, Chan LY, Lai KN, Tang SC: Downregulation of renal tubular Wnt/beta-catenin signaling by Dickkopf-3 induces tubular cell death in proteinuric nephropathy. Cell Death Dis 2016;7:e2155.

-34 Lin SL, Li B, Rao S, Yeo EJ, Hudson TE, Nowlin BT, Pei H, Chen L, Zheng JJ, Carroll TJ, Pollard JW, McMahon AP, Lang RA, Duffield JS: Macrophage Wnt7b is critical for kidney repair and regeneration. Proc Natl Acad Sci U S A 2010;107:4194-4199.

-35 Saulnier DM, Ghanbari H, Brandli AW: Essential function of Wnt-4 for tubulogenesis in the Xenopus pronephric kidney. Dev Biol 2002;248:13-28.

-36 Szeto HH, Liu S, Soong Y, Wu D, Darrah SF, Cheng FY, Zhao Z, Ganger M, Tow CY, Seshan SV: Mitochondriatargeted peptide accelerates ATP recovery and reduces ischemic kidney injury. J Am Soc Nephrol 2011;22:1041-1052.

-37 Mukhopadhyay P, Horvath B, Zsengeller Z, Zielonka J, Tanchian G, Holovac E, Kechrid M, Patel V, Stillman IE, Parikh SM, Joseph J, Kalyanaraman B, Pacher P: Mitochondrial-targeted antioxidants represent a promising approach for prevention of cisplatin-induced nephropathy. Free Radic Biol Med 2012;52:497-506.

-38 Tao GZ, Lehwald N, Jang KY, Baek J, Xu B, Omary MB, Sylvester KG: Wnt/beta-catenin signaling protects mouse liver against oxidative stress-induced apoptosis through the inhibition of forkhead transcription factor FoxO3. J Biol Chem 2013;288:17214-17224.

-39 Lento W, Ito T, Zhao C, Harris JR, Huang W, Jiang C, Owzar K, Piryani S, Racioppi L, Chao N, Reya T: Loss of beta-catenin triggers oxidative stress and impairs hematopoietic regeneration. Genes Dev 2014;28:9951004.

-40 Valle I, Alvarez-Barrientos A, Arza E, Lamas S, Monsalve M: PGC-1alpha regulates the mitochondrial antioxidant defense system in vascular endothelial cells. Cardiovasc Res 2005;66:562-573.

41 Tran M, Tam D, Bardia A, Bhasin M, Rowe GC, Kher A, Zsengeller ZK, Akhavan-Sharif MR, Khankin EV, Saintgeniez M, David S, Burstein D, Karumanchi SA, Stillman IE, Arany Z, Parikh SM: PGC-1alpha promotes recovery after acute kidney injury during systemic inflammation in mice. J Clin Invest 2011;121:40034014.

42 Tabara LC, Poveda J, Martin-Cleary C, Selgas R, Ortiz A, Sanchez-Nino MD: Mitochondria-targeted therapies for acute kidney injury. Expert Rev Mol Med 2014;16:e13.

43 Yoon JC, Ng A, Kim BH, Bianco A, Xavier RJ, Elledge SJ: Wnt signaling regulates mitochondrial physiology and insulin sensitivity. Genes Dev 2010;24:1507-1518.

44 Liu B, Zhang R, Tao G, Lehwald NC, Liu B, Koh Y, Sylvester KG: Augmented Wnt signaling as a therapeutic tool to prevent ischemia/reperfusion injury in liver: Preclinical studies in a mouse model. Liver Transpl 2015;21:1533-1542. 